\title{
Circuit
}

Musiques contemporaines

\section{Travelogue pour un Marco Polo [My Travels with Claude?]}

A journey through the composer's life and work in 10 days

Récit de voyage pour un Marco Polo [Mon voyage avec

Claude ?]

\section{Parcours en dix journées à travers la vie et l'oeuvre du compositeur}

\section{Stephen Rogers}

Volume 18, numéro 3, 2008

Claude Vivier, vingt-cinq ans après : une introspection

URI : https://id.erudit.org/iderudit/019138ar

DOI : https://doi.org/10.7202/019138ar

Aller au sommaire du numéro

Éditeur(s)

Les Presses de l'Université de Montréal

ISSN

1183-1693 (imprimé)

1488-9692 (numérique)

Découvrir la revue

Citer cet article

Rogers, S. (2008). Travelogue pour un Marco Polo [My Travels with Claude?]: A journey through the composer's life and work in 10 days. Circuit, 18(3), 27-51. https://doi.org/10.7202/019138ar
Résumé de l'article

Dans son article, Stephen Rogers propose une interprétation du travail de Claude Vivier et de son rapport particulier au thème du voyage. C'est un travail de réflexion qui s'attache davantage à la description, plutôt qu'à l'analyse. Les lecteurs pour qui les techniques utilisées par Vivier pour créer sa musique sont familières retrouveront certaines d'entre elles à l'oeuvre dans l'article de Rogers, mais appliquées à l'écrit, plutôt qu'au sonore. 


\section{LAURÉAT DU CONCOURS INTERNATIONAL DE RÉDACTION D'UN TEXTE SUR CLAUDE VIVIER}

\section{Travelogue pour un Marco Polo [My Travels with Claude?] :}

a journey through the composer's life and work in 10 days

Stephen Rogers
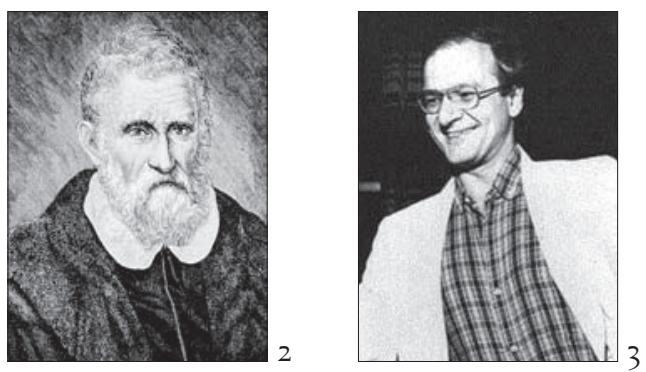

1. Co-produit avec la SMCQ. Jury du concours: Jonathan Goldman (Circuit; University of Victoria), Sean Ferguson (SMCQ; McGill University) et David Metzer (University of British Columbia).

2. Portrait of Marco Polo from $<$ http://upload.wikimedia.org/ wikipedia/commons/5/54/Marco_Polo_ portrait.jpg $>$ (23 March 2008)

3. Photo of Claude Vivier from $<$ http://bilan.usherbrooke.ca/voutes/ voute/vivier.jpg > (23 March 2008)

Itinerary One: Days 1 to 3

Every journey has to start somewhere, yet every beginning is a continuation. This itinerary, the first of four, offers the traveller three versions of the beginning of a pleasant journey with Claude. However, for many this journey will have already had a beginning, at some point in the distant past or perhaps just a day or two ago. These travellers may view the current journey as a revisiting rather than an initiation, the resumption of an ongoing conversation. 


\section{Day 1: Questionable Beginnings}

In 1976 Vivier embarked on his extended and oft-mentioned trip to [into?]

the "East". This, one might say, was the beginning [continuation?]

of a lifelong fascination with the Orient and all that it represents

[hides?]

Most famously he spent a significant amount of time in Bali but also visited

[imagined?]

several other locales

[dreams?]

including Thailand, Japan, India and Iran.

[orient?]

In the present age where "rapid means of transport have deprived arrivals of any significance"4, the closest we often get to the places through which we travel is a cruising altitude of 25,000 to 35,000 feet, where towns and villages are nothing more than:

$\begin{array}{lll}\text { unlit } & \text { [fires?] } & \text { networks of interconnected street lights } \\ \text { in the midst of } & \text { [deserts?] } & \text { oases of grey concrete } \\ \text { surrounded by } & \text { [seas?] } & \text { apparently uninhabited islands. }\end{array}$

In row $x /$ seat $y$ we acknowledge the fact that these are places, yet from the sky they cannot be more than abstractions of places, more akin to a piece of art than a living, throbbing, inhabited place. Yet, a piece of art-or at least those we deem worthy - is a type of organism which breathes, throbs, functions, lives, despite the fact that we label it artifice or artefact for the very reason that it is not real but reflective; not a mother tongue but a translation.

4. Maraini, 2000, p. 232.

5. Aerial photo of Paramaribo, Suriname from http://upload. wikimedia.org/wikipedia/ commons/thumb/5/58/

Paramaribo_55.20082W_5.85569N. jpg/80opx-Paramaribo_55.20082W 5.85569N.jpg (25 March 2008)

6. Aerial photo of Shiraz, Iran from http://www.parstimes.com/ spaceimages/shiraz_640.gif (25 March 2008)
What then do we make of Claude Vivier, someone who makes works of art, someone who lives in a perpetual state of mental journey even when planted firmly in one place?

How do we situate one who demonstrates an unwillingness to remain still?

In the face of these questions, the trip of 1976 is promoted to the position of a culmination rather than the beginning of the journey of Claude Vivier. In the face of this realization, one is reminded that there are numerous modes of travel, not all of which involve some form of physical motion [translates?]

[virtual?]

[inability?]

[relegated?]

[component?]

[life?]

[forcefully?]

[repudiate?]

[stillness?]
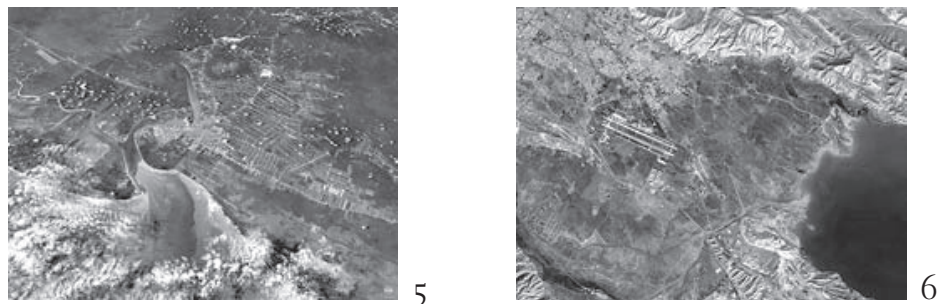


\section{Day 2: Second Beginnings}

In times not too distant from our own, when record keeping was not what it is today, nearly every life-story began in obscurity. With that obscurity came a window of opportunity in which a person could generate a mythology about his own origins during which time no one could exclaim, "That's not true!"

Vivier, born in a time of abundant record-keeping, had the misfortune of being born to unknown parents. As such he would always be surrounded by a certain degree of obscurity and mystery. Vivier's orphan status is as frequently touched upon by those who write about him as his untimely demise. Between these two pillars of obscurity lies a life dictated by travel, on innumerable paths, and with several terminae. The terra incognita of Vivier's life may be the most fertile for study, yet, its continual shifting may also make it the most difficult. For those who wish to walk down this path, we must look at more than the composer's footprints [his own?]

[what is?]

[certain uncertainty?]

[a composer?]

[true story?

[with conviction?]

[good fortune?]

[entitled to?]

[birth-story?]

[near inevitable?

[sign-posts?]

[perpetual paths?]

[no apparent?]

[fruit bearing?]

[endless obscurity?]

[follow along?]

[curriculum vitae?]

[mere speculation?] We must inquire into Vivier's state of mind

[mind set?]

[exact strata?]

[a choice?]

[reveals itself?]

[its relative?] in order to better interpret the numerous twists and turns along the path.

Accuracy becomes invalid

in the face of a truth which, though ultimately unavoidable,

can be defined not as truth but as its very antithesis

reality.
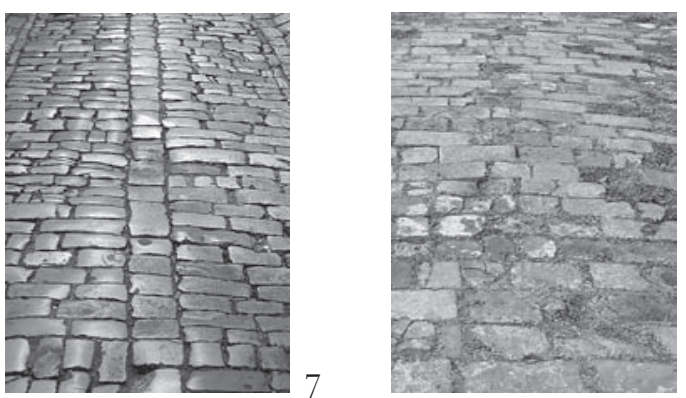

7. Photo of a street in Trogir, Croatia by the author. (June 2005)

8. Photo of the Great Wall of China at

8 Simitai by the author. (September 2006) 


\section{Day 3: Alternate Beginnings}

Despite his best efforts to integrate into the societies he visited,

[to "find himself"?] especially Bali, Vivier could be considered a mass tourist.

The 1960s and 7os saw a staggering influx [just another traveller?]

[large scale invasion?]

[Levant left alone?] of western travellers to the once inhospitable East. The musicians of Bali even developed a special type of gamelan to be played for tourists in lieu of the genuine article(s).

[authentic but sterilized?]

There is an infinite replication of trips to the point that even a formerly extraordinary voyage - to Machu Picchu, say, or to the Forbidden City or to Tashkent-has become something rather ordinary, a kind of norm rather than an escape from the norm. 9

[arrivals vs. departures?] [postcards for posterity?] [head of steam?]

What point, then, in undertaking a journey of any kind?

What impetus can exist to travel to unknown places that are so well-known? He may not do so consciously, but a traveller must often accept the fact that he travels for the sake of travelling and, fundamentally, nothing more.

[the proverbial journey?] It is the act of travel

[not the destination?] which holds more value than the ins and outs of the places to which one travels.

Undertaking a trip requires moving from a location which is known toward one that is not. For Albert Camus, it is this fear of the unknown and the overcoming of the desire to return to the familiar that makes travel a valuable endeavour. ${ }^{10}$ Georges van den Abbeele asks, 'Is not that movement outwards then what defines the very inside one is supposedly trying to leave?"

Here then we must picture both Vivier the orphan and Vivier the corpse; the path between them beset with works of art. are the various attitudes held by the composer toward travel. These attitudes are multiple and varied but also inextricable from one another

[lost and found?] [itineraries of itinerants?] [under the bridge?] [and his entourage?] [in one sense?] [repelling one another?] 
The artistic exploration of a place

$$
\text { cannot replicate }
$$

[but can evoke?]:

the smell of the near stagnant waters of the muddy river

the bird calls of the dense jungle piercing the impenetrable canopy of green

the fear worn on the skin of the traveller when utmost darkness,

a different darkness from that in the West, descends.

The artistic exploration of a place

can evoke

[but cannot replicate?]:

the desires held closest to the artist's heart

the various attitudes held by the artist toward travel, both literal and metaphorical the reconciliation of the vastly different but incredibly similar processes

of creating art and undertaking travel.

Whether or not it is frozen or flowing it is still water.
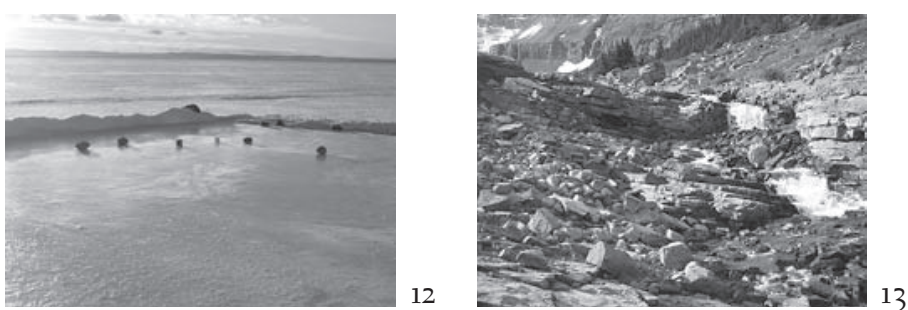

12. Photo of Lake Wabamun, Alberta by the author. (December 2006)

13. Photo of Lake of the Falls, Alberta by the author. (August 2007) 


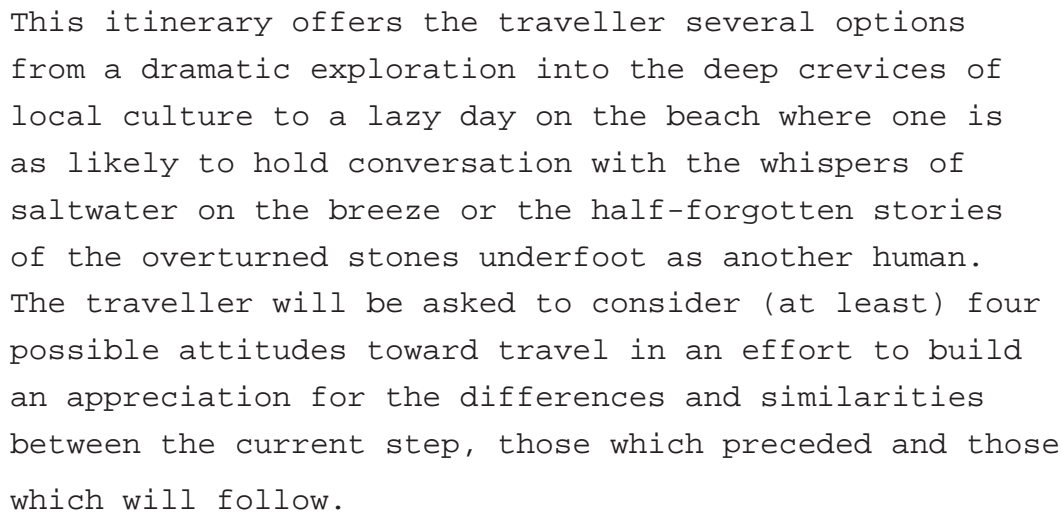

\section{Day 4: Attitude 1, Real Travel}

A voyage is initially defined in grammatical terms as the "transport of a person from the place where one is to another place that is far enough away." Travel is thus first defined from an anthropological perspective: it refers to the movement of human beings, of "a person," from one place to another. ${ }^{14}$

Of the various modes of contact with a foreign culture none can be more physically explicit than the type of interaction which sees the traveller actually set foot within the location to which he desires to travel and then, stay there for a while. Frequently, if a sufficiently strong relationship between the two parties is allowed to develop, the life of the traveller will bear the markings, to various degrees of palpability, of the place in question. Assimilation is the end product of this type of attitude toward travel; however, it is an extremely slow process which is seldom allowed to fully mature.

This attitude is reflected clearly in the output of Claude Vivier. Several of his musical works bear the markings of his first-hand experiences with the musical traditions of those places through which he travelled. The Indonesian island of Bali was the site of Vivier's greatest cultural immersion. No piece of his illustrates this attempted integration more so than Cinq chansons pour percussion composed in 1980 (though others such as Pulau Dewata and Siddharta do explore similar terrain). Vivier learned how to speak the local languages and even received a Balinese name, Nyoman Kenyung ('the laughing third-born'). ${ }^{5}$ The music of Cinq chansons reflects an effort on Vivier's part to exhibit and explore a one-to-one relationship between his own musical style and that of his adopted and temporary home, Bali.
15. von der Weid, Jean-Noël, p. 15 
Composed for percussionist David Kent, a friend of Vivier's, the piece is composed for a number of metallic percussion instruments, including the famous Balinese instrument, the trompong, but also several other instruments encountered by the composer during his travels through other parts of East Asia. Thus, we see the inclusion of Thai nipple gongs, Japanese changs, and a Chinese gong in addition to the trompong. Despite this mixture of instruments, it is the musical style of Bali which blends most thoroughly with Vivier's pre-existing-but ever-changing-style.

EXEMPLE 1. Instrumentation of Vivier's Cinq chansons pour percussion, 1980. ${ }^{16}$
16.Vivier, Claude, 1989, p. 2.

\section{INSTRUMENTATION}

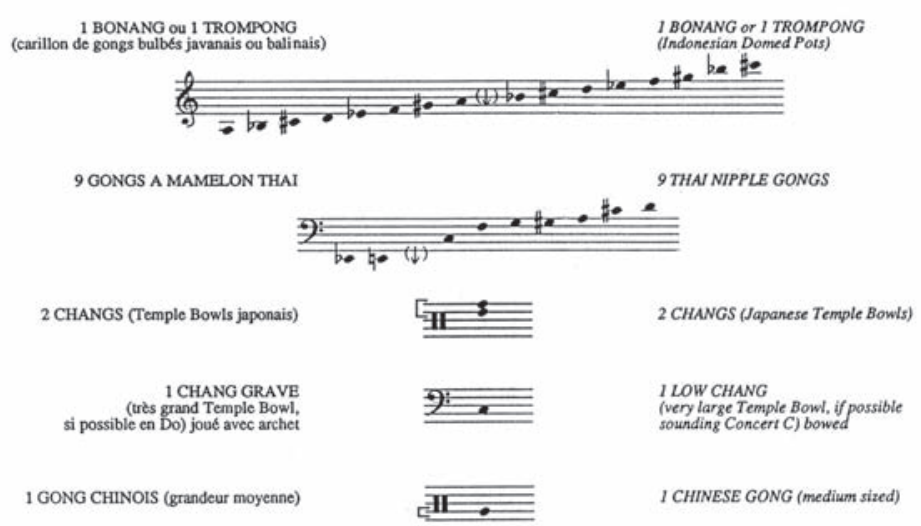

Nous remercions David Kent, percussionniste, et Jose Evangelista, compositeur, pour leur preceieuse collaboration à cette edition. We thank David Kent, percussionist, and Jose Evangelista, composer, for their valuable contribution to this edition.

A closer look at the second of the Cinq chansons, entitled Chanson à midi (perhaps a homage to the Hindu tradition of reserving certain songs for certain times of day?), shows quite clearly the amalgamation of Vivier's aesthetic with certain elements of the Balinese musical tradition. An overview of some of these Balinese characteristics following David Harnish's article from the Garland Encyclopedia of World Music explains the basics of gamelan music:

Balinese ensemble music is often characterized by the term stratified polyphony, though the various melodic lines are usually rooted in the same melodic flow. The music basically consists of a nuclear melody, the pokok 'trunk', within a cyclic metric 
17. Harnish, David, 'Bali', in Garland Encyclopedia of World Music: Volume 4: Southeast Asia, Terry E. Miller and Sean Williams, eds., New York, Garland,1998, pp. $733-734$ structure. Some instruments perform the pokok; some punctuate it; some play an expansion or elaboration of this melody; some perform metrical punctuation; and one or two groups of instruments normally play figurations (kotekan) to create multiple layers of musical sound. The higher-pitched instruments, considered the least important to a given composition, usually perform in figuration. These interlocking figurations, in which two musicians play parts of a single line, are found in nearly every type of orchestral music and constitute one the distinguishing characteristics of Balinese music. ${ }^{17}$

EXEMPLE 2. Claude Vivier: Chanson à midi (first page), 1980.
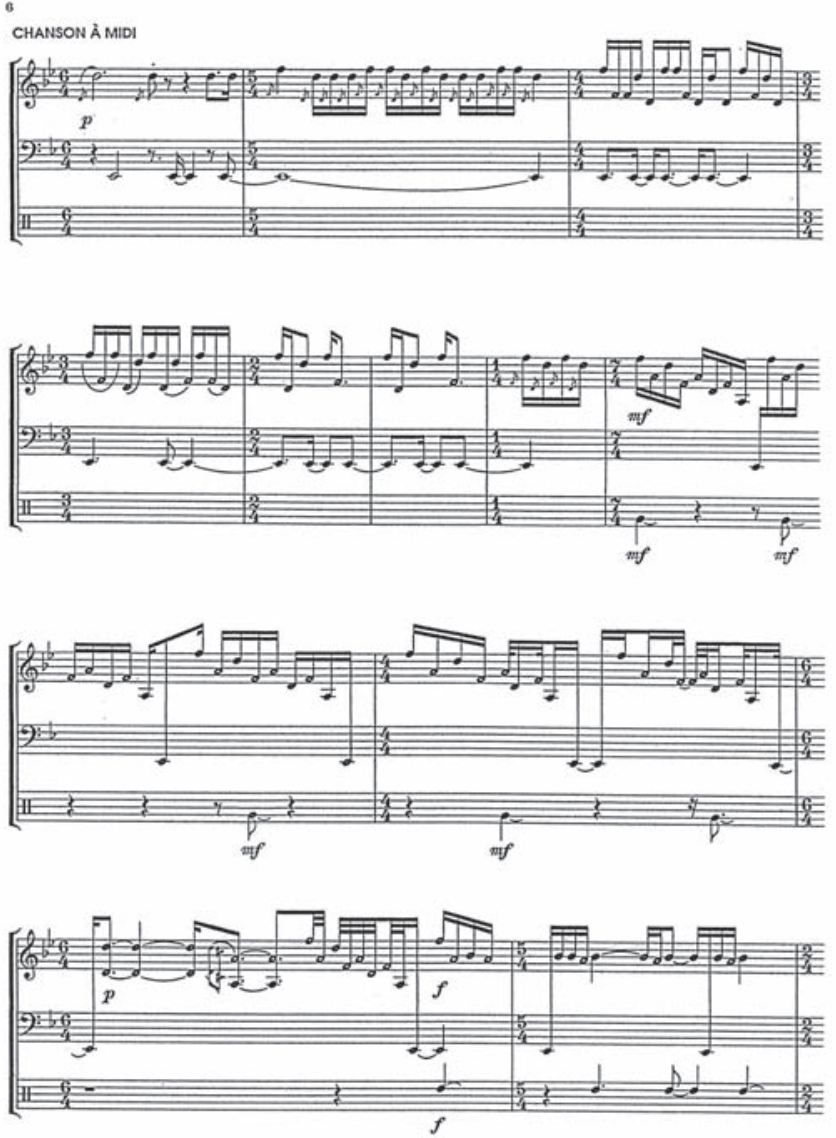

The pentatonic scale dominates Balinese music. There are two pentatonic systems, known respectively as pélog and sléndro. Sléndro consists of five equally spaced tones within the octave, while pélog is a seven-note mode built of unequal intervals from which various pentatonic scales can be 
derived by removing two pitches. The five notes of these scales are assigned the onomatopoeic names dong, dang, dung, deng, and ding. Whatever pitch is assigned to the role of dong assumes the role of a tonic, or rather, the most important pitch. Dang and dung are respectively equivalent to the dominant and subdominant of western music, exhibiting a fifth relationship to dong. Deng and ding are the least important of the five pitches. Sometimes, in pélog rather than omit two notes completely in order to make a pentatonic scale, the "extra" two pitches are relegated to the role of ornamental notes, filling the gaps between the largest intervals within the scale.

With this limited information in hand, it is possible to evaluate the influence of Balinese musical characteristics in the Chanson à midi of Vivier's Cinq chansons.

Vivier's interpretation of the various strata of Balinese music illustrates his need to simplify the characteristic polyphony to make the work performable by a single percussionist. The three staves clearly indicate three layers heavily influenced by Balinese musical concepts. The upper stave illustrates a quasikotekan layer which is played on the trompong. The middle stave interprets a kind of pokok layer in which the Thai nipple gongs sing out a slow-moving "melody" in the middle register of the "ensemble". The lower stave can be read as a colotomic layer in which the changs and gongs punctuate the cyclic aspects of the pokok and mark dramatic breaks in the piece. In most Balinese gamelan ensembles, there would be a fourth layer, consisting of the drums kendang lanang ("male") and kendang wadon ("female") one of which is usually performed by the ensemble's leader (conductor). Vivier presumably omitted this layer for practical reasons pertaining to solo performance.

Vivier's pitch material corresponds closely with a version of the pélog scale of Balinese music known as pélog selisir. The additional notes in Vivier's version are used sparingly (the C-sharp only once, in measure 11) and often in the aforementioned ornamental role sometimes given to the left over notes from the original heptatonic scale from which the pentatonic pélog is derived.

FIGURE 1. Pélog selisir in Vivier's Chanson à midi

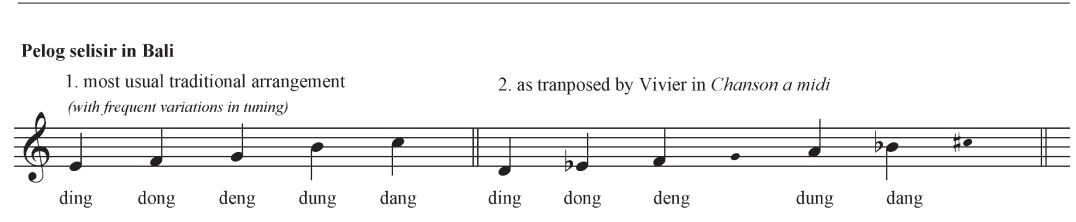


Furthermore, Vivier carefully designed a hierarchy for his pitches. In the opening measures the low E-flat of the middle stave is clearly given the role of dong or tonic. This note is seldom missing from the overall sonority of the piece, though what is played against it is frequently changed. The upper stave begins with only Ds and Fs, ding and deng respectfully, which flank the E-flat. In measure 8, the Chinese Gong marks the entry of the A (dung) in the upper stave and when the Chang enters on the final beat of measure 11, the last of the pentatonic scale degrees, B-flat (dang) is sounded in the Trompong. These triggering effects demonstrate clearly, the colotomic function of the Changs and Gong.

Though it could be viewed as a mere coincidence of the intervallic nature of pélog selisir, Vivier not only found but exploited an axis of symmetry within the pitches of the scale. In typical fashion he clearly illustrates the melodic process through which this symmetry is revealed. The opening seven measures of the upper stave consist solely of two pitch-classes, D and $\mathrm{F}$ but in two pairs an octave apart from one another giving a total of four pitches. When the fifth pitch, A, is added, it splits these two pairs near the middle, creating an asymmetry for the first time. The gong in the lower stave marks the cycle over which this asymmetry presides. When the chang enters on the final beat of measure eleven, the symmetry of the upper stave is re-established, but not by removing the A, but by adding a B-flat. These two pitches form an axis of symmetry between the two pairs of Ds and Fs. And, as mentioned before, the entrance of the B-flat marks the first time that all five pitches of pélog selisir are present.

FIGURE 2. Symmetrical nature of notes of upper stave in Vivier's Chanson à midi

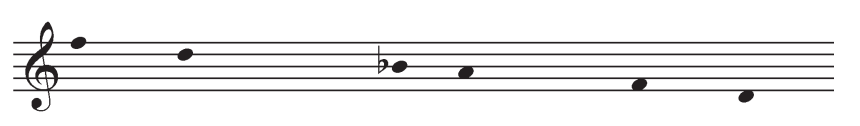

Other typical Vivier techniques can be viewed in the opening measures of Chanson à midi. The metres of the opening seven measures (the first cycle?) descend in an obvious pattern $6 / 4,5 / 4,4 / 4,3 / 4,2 / 4,2 / 4$, and 1/4. Rather than stand out as an anomaly, the two $2 / 4$ measures, which are identical in content, are very typical of Vivier in the way that they momentarily break the pattern and somehow suspend the forward progress of the piece. Following the $1 / 4$ measure, with the entrance of the gong, a second cycle begins which takes place over the next three measures. The gong attacks also very clearly bear 
Vivier's fingerprints. The space between its attacks being respectfully 3 eighth notes, 5 eighth notes, 4 eighth notes and finally 2.5 eighth notes which, as the first non-integral duration, once again constitutes another break in the pattern marking the impending end of the cycle.

The rhythmic organization of most Balinese music is much more regular than what we see in Vivier's Chanson à midi yet its overall conception is remarkably similar. Large-scale cycles are marked as they start and finish and eventually-sometimes surprisingly but other times mercifully-the cyclic pattern is altered and the musicians find a 'new groove'.

Overall, it is not only possible to see, but rather, impossible not to see the relatively balanced interplay between the two major musical characters of the piece. On one hand, we have Claude Vivier, a man of indeterminate origin and varied life experience, and on the other Nyoman Kenyung, much younger than his Doppelganger, but certain of his origins on the Island of the Gods with its white sand beaches like a giant set of lips opened in a hearty laugh to reveal the volcanoes on the inside like giant teeth, both beautiful and foreboding.

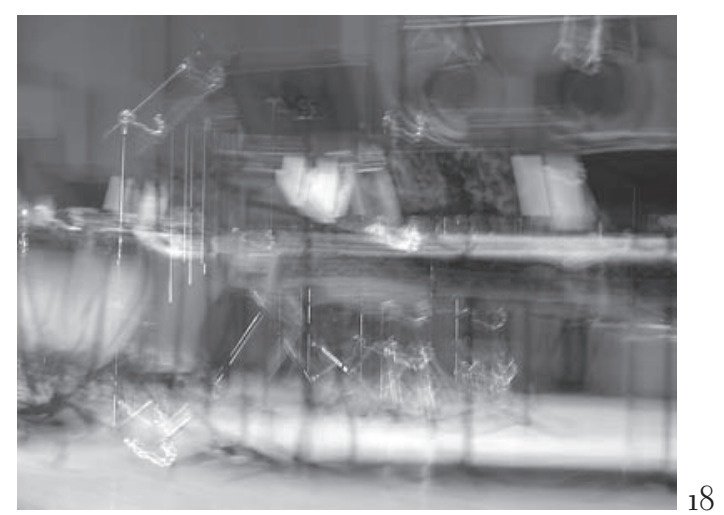

18. Photo at Schulich School of Music, McGill University by the author. (April 2008) 


\section{Day 5: Attitude 2, Evocative Travel}

When considering the influence of the musical traditions of the East upon the work of Claude Vivier, we cannot discard completely his travels to places other than Bali despite the fact that in no place other than the "Island of the Gods" did he put forth such a pronounced effort toward his own integration into the local musical culture. His travels included other destinations with other experiences. In Japan, he attended kabuki theatre, and was struck by the ritual-like nature of that art form and perhaps translated some of those elements into later works. In India he had the opportunity to encounter first-hand those aspects of the melodic system known as râga of which he had enjoyed first contact during his studies with Gilles Tremblay and Karlheinz Stockhausen. In Iran he may have heard the muezzin's voice issuing forth from the top of a minaret calling the faithful to prayer.

Yet, the majority of Vivier's experiences during his travels from 1976 to 1977 lie shrouded in mystery. What did he do in the places he visited? Exactly where did he go? Can we trust that the pieces apparently inspired by those locations through which he passed are representative of the true physical journey he undertook? Can we be sure that Vivier, who at best passed through some of these places, had developed anything beyond a superficial understanding of those cultures with which he came into contact?
No one, wise Kublai, knows better than you that the city must never be confused with the words that describe it And yet between the one and the other there is a connection. ${ }^{19}$

This journey to the Orient brought with it the appearance of new sound effects, characteristic timbres, boldly exaggerated by Vivier, but which, paradoxically, open a new spareness of expression on the one hand and, on the other, a highly personal conception of phrasing, and of the social and concrete role of music (the artist as the basis of social organization). ${ }^{20}$

The richest streets radiated to the centre from the gates. They were too narrow for two carts or camel caravans to pass by each other, so one had to back up or turn into a side lane and wait for the other to pass by. ${ }^{21}$

The function of [the] kuroyo is also very astounding, they are all in black and are not supposed to be seen! In fact they are not seen! They serve, handle stage property, the onnayata male playing female roles. ${ }^{22}$
19. Calvino, Italo, Invisible Cities, trans. William Weaver, London, Vintage, 1997, p. 61

20. von der Weid, 2003, p. 15

21. Arapov, Dmitriy Yu., [Introduction to] Bukhara, Vitaly Naumkin, ed. Reading, Garnet, 1993, p. 21.

22. Vivier, Claude, "Japon", in Circuit, vol. 2 , nos. 1/2, 1991, p. 68 
A glance at the catalogue of Vivier's works clearly shows that he strove to create and foster an artistic relationship between his artistic output and the cultures of those places he may (or may not) have visited. These pieces, which include Shiraz, Zipangu, Samarkand and Bouchara, bear witness to a different attitude toward the relationship between art and travel from works such as Cinq chansons pour percussion. Where a certain symbiotic relationship, one of a mutual borrowing between two tangible musical cultures (that of Bali and that of Vivier) was developed in Cinq chansons, in a work like Bouchara, one is left to wonder if there is anything at all Bukharan (or more generally, Central Asian) in the music at all. Perhaps the only elements of Bukharan culture in Vivier's piece are interpretations or evocations rather than replications or even translations. In Cinq chansons, the fingerprints of Balinese music are evident in both the score and the aural manifestation of the score. In Bouchara a higher degree of forensic diligence is required to locate these fingerprints and even if this were possible, one would still wonder if what he is seeing is a fingerprint at all, or something else, something that cannot be used for absolute identification; a clue perhaps, but certainly not evidence.

This attitude toward the relationship of travel to art (art to travel), relies more heavily on the imagination and experiences of the listener. While even the most inexperienced listener will hear the instrumentation and pentatonic mode of Cinq chansons as something 'Eastern' or 'Asian-influenced', with Bouchara et al, the referencing is more subtle, more austere. So it is perhaps the listener's experience
The integrity of the common tune is overwhelmingly preserved in each item despite melodic and rhythmic variations. ${ }^{23}$

The melodic development of each shu'be progresses through a series of structural divisions distinguished by tessitura: an introductory section, darāmad, set in a low tessitura leads to a section called miyānkhāna typically set at the interval of a fifth above the introduction. Miyānkhāna leads to dunasr, set an octave above the darāmad. Awj 'zenith', 'culmination' follows dunasr, after which the piece gradually descends to the original tessitura in a concluding section called furāward. The hightessitura awj is both the musical and dramatic climax and may assume various named canonical forms, such as awj-i turk, muhayyar, and zebā pari. Awj may also include melodic fragments drawn from another shu'be, called namud, which help create melodic unity in the maqām cycle as a whole. ${ }^{24}$

It was prohibited to ride past the mazar. Riders dismounted on their approach to the mazar and walked past it, leading their horse or other animal. According to legend, the mazar could throw a rider who had not dismounted out of ignorance or lack of respect. ${ }^{25}$
23. Levin and Sultanova, 1997-2002, p. 911

24. Ibid., p. 911

25. Naumkin, 1993, 120 
and imaginative scope which determine to what extent Vivier's work evokes the place. Ambiguity is increased in the case of Bouchara (as in Samarkand, Shiraz and Zipangu) in the way the piece may evoke a place which exists more in a legendary (sacred) space and time than in the (secular) here and now. Vivier's work, in this way, manages to evoke elements of the place's history and culture which may no longer be evident in the present day. He draws upon a stagnant place, a place that was once vibrant but no longer possesses its old lustre.

Depending on what our own experience of the place may be, when listening to Vivier's Bouchara we might hear:

1. A funeral lament

2. An organ with unknown stops, filling the corners of an empty cathedral

3. A child, lost in the desert

4. The scorned wife of an itinerant merchant

5. The dream of a child, lost in a maze of city streets, navigating by the sound of his mother's voice which he does not realize is only in his mind

6. The memory of a dream about a child or a city

7. A song heard near the window of some dilapidated casa

8. A bazaar, long since abandoned, with sunlight pouring through holes in its canopy

9. none of the above

10. all of the above
Performed as a suite rather than, as became common in Soviet times, individual pieces taken out of context, the shash maqam is revealed as an extended metaphor of life itself: a musical and poetic journey through the emotional and spiritual worlds of human existence. ${ }^{26}$

As he began to dance, a barefooted bacha stood on tiptoes. He held his left leg straight and jumped lightly on it, keeping time to the music. His right leg was bent in the knee and now and then he would touch his left leg with it. He kept his elbows raised throughout the dance. He put his palms to his face and took them away in time to the music. At some point the bacha clapped his hands several times but more frequently joined his palms, put them to his face and snapped his fingers loudly in time to the music. ${ }^{27}$

The application of the metaphor of travel to thought conjures up the image of an innovative mind that explores new ways of looking at things or which opens up new horizons. That mind is a critical one to the extent that its moving beyond a given set of preconceptions or values also undermines those assumptions. Indeed, to call an existing order (whether epistemological, aesthetic, or political) into question by placing oneself "outside" that order, by taking a "critical distance" from it, is implicitly to invoke the metaphor of thought as travel. ${ }^{28}$
26. Levin and Sultanova, 1997-2002, p. 920.

27. Naumkin, 1993 , p. 120

28. van den Abbeele, 1992, p. xiii. 
In works like Bouchara Vivier reminds us of the traveller's historic role of storyteller. Like a Marco Polo, he sits us down in a chair, tells us a tale, of his own travels, of the places to which he has journeyed, and then, when the telling is over, he looks us in the eye and says, "and that's the true story.' Looking at him through his thick glasses - and perhaps our own - it is difficult to tell whether he expects to be taken seriously or not. Yet, the telling of the tale has been so skilful as to cast the whole issue into doubt. The wink that we think we see him give us can be interpreted variously:

a. "Unbelievable as it may be, that's exactly how it happened."

b. "I may have exaggerated a bit here and there."

c. "Don't believe a thing I have said."
One could buy there virtually everything manufactured in the East or West: namely clothes, fabrics, scents, medicine, plates and dishes, other household utensils, old coins from all over the world, and jewellery. ${ }^{29}$

Did you ever happen to see a city resembling this one?" Kublai asked Marco Polo, extending his beringed hand from beneath the silken canopy of the imperial barge, to point to the bridges arching over canals, the princely palaces whose marble doorsteps were immersed in the water, the bustle of light craft zig-zagging, driven by long oars, the boats unloading baskets of vegetables at the market squares, the balconies, platforms, domes, capaniles, island gardens glowing green in the lagoon's grayness..$^{\circ}$

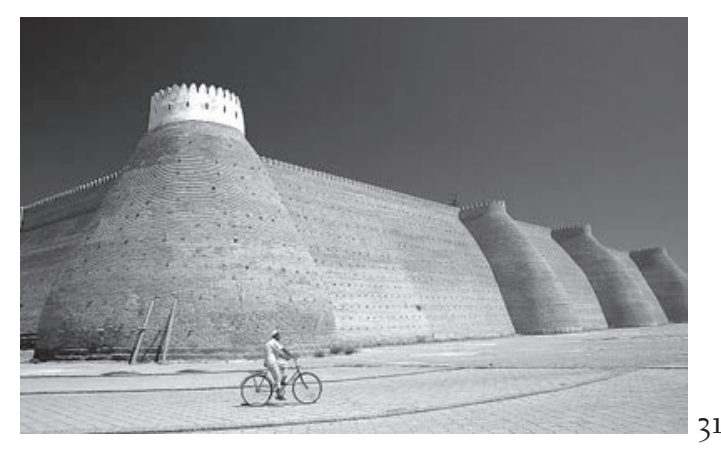

29. Naumkin, 1993, p. 92.

30. Calvino, 1997, p. 85.

31. Photo of cyclist outside of Bukhara, Uzbekistan from < http://www.

trekearth.com/gallery/Asia/Uzbekistan/ West/Bukhara/photo562214.htm>

(8 March 2008) 


\section{Day 6: Attitude 3, Imagined Travel}

32. Leed, op. cit., p. 19.
The Atwater Market rather than the Toki Saraffon Bazaar of Bukhara.
The inability to regard place as anything but territorial, the eternal assumption that societies are boundaried, centered, contained, and enduring structures, is a distortion of retrospect, a view of history filtered through the results of history. $3^{2}$

We in the West often refer to it as arm-chair travel but it can be just as easily accomplished from the chesterfield or kitchen table. This type of travel, unceasing in some individuals, is both initiated and propagated by the mind. The body is either stationary or moving in a far different plane than the mind.

\begin{tabular}{|l|}
\hline $\begin{array}{l}\text { The Atwater Market rather } \\
\text { than the Toki Saraffon Bazaar } \\
\text { of Bukhara. }\end{array}$ \\
\hline
\end{tabular}

The Memorial Swimming Pool at McGill University rather than the Baths of the Zand Citadel in Shiraz.

The logistics of travel - of getting from one place to another - are superseded by the far less rigorous logistics of the imagination.

However, some rules apply:

1. Acknowledge a set of parameters or a relationship between the imaginative journey and the actual journey (were it to have existed or were it to potentially take place at some future date).

2. Replace the physical paths of travel with imaginary ones which, though very different, provide the opportunity for the traveller to attain some form of motion.

3. Realize that the ultimate goal of any voyage, whether real or imagined, is tied up in notions of attainment (of spiritual richness, intellectual wealth, philosophical currency) and of loss (of sense of place and/or time, sense of innocence, sense of self)

In the world of Claude Vivier, we will never know just how far reaching was this type of travel. In his artistic output every piece could be thought of as a representation of some form of imagined travel, some with physical travels as counterparts, and others with speculation on all sides. 
This attitude toward travel was Vivier's mode of transportation to the South American city of Paramaribo. He exchanged a plane ticket for a stack of manuscript paper: seat $a /$ row $i$ for one version of $a$ speculative journey to a city he would never see but would explore in great depth.

Just as the Dutch exchanged their colony New Amsterdam (today's island of Manhattan) with the British for that city at the mouth of the River Suriname.
Souls were traded from this colony to that; the Dutch East Indies transported to the ("western"?) waters of the Caribbean; entire gamelans exchanged for a bird song.

Paramirabo is the result which, as a piece of music, may or may not have anything to do with the sounds of Paramaribo. Rather, this is how Vivier imagined Paramaribo, or some place like it... or not quite like it. Often times, certain questions go unasked but are, in truth, omnipresent: "Which other places, other journeys, can be seen in the one presented on the surface? What other voices can be heard?"
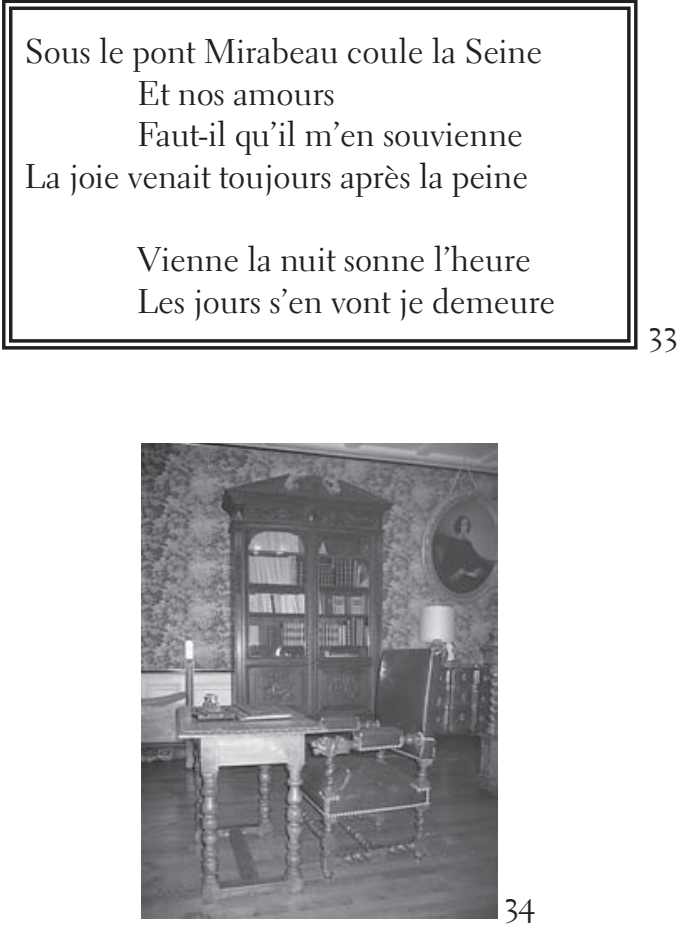

33. Apollinaire, Guillaume, "Le pont Mirabeau" (1908)

34. Photo of house near St. Flour, France by the author. (May 2005) 


\section{Day 7: Attitude 4, Vicarious Travel}

35. Bergreen, 2007, p. 36.

36. Tannenbaum, 1991, p. 14.

Stunning developments awaited them. Niccolo learned that his wife was dead. Perhaps even more startling, she had left him a "small son of fifteen years who had the name Marco." This was Marco Polo, a boy who had spent his entire life in Venice, had never known his father, and until Niccolò's return had had every reason to believe that he was an orphan. 35

It is not clear to what extent Claude Vivier identified himself with the great Venetian traveller (storyteller) Marco Polo. Perhaps this is as it should be. Despite the seven centuries between them and the innumerable differencesthe two manage to exhibit a large number of similarities.

Beginning with his studies with Gilles Tremblay, who in turn studied with Olivier Messiaen, and continuing with his time under the tutelage of Karlheinz Stockhausen, Vivier's fascination for both Christian and Oriental philosophy and culture was evident. ${ }^{6}$ His lengthy journey through the Orient served to cleave these two fundaments: in this way he managed to simultaneously embrace and repudiate the two ways of life which served to both unify and diversify his personal path. Upon his return from Bali, Claude enjoyed a certain celebrity in his home city, where many regarded him with light-hearted suspicion: his idiosyncrasies became terms of endearment, his habits perhaps unappreciated but tolerated nonetheless because of who he was and what he had done. His imprisonment, in reality a form of house-arrest-perhaps even self-imposed-, enabled and forced the artistic output which issued forth after his travels. The more he produced the more he came to wonder, even to himself, if what he remembered was at all accurate or whether through the filter of his own memories, the true paths, histories, experiences had been obliterated and replaced with other paths, histories, experiences, no less interesting or authentic despite their apparent inaccuracy. Not once did he feel as though his art were too autobiographical, too personal. "Let them wonder which one of those thousands is really me," he thought on more than one occasion. When he died in a dark European apartment, people wept because he was gone and with him any chance of deciphering the codes of his art. Yet, as time passed, some began to realize that it may be better not to know: some came to prefer the approximate over the exact, the likely-false over the probably-true. Rustichello and his other friends preferred to remember him in their own way and though they could not attest to the veracity of any of his stories at least they could say that they had heard them first-hand. Meanwhile others were still snidely asking, "Hey, Marco, where are your millions now?" This is the type of person who fails to 
realize that the truth doesn't rest long enough to be counted and even if one were able to somehow touch it, even for a fraction of a second, it is not only constantly in motion but also in a perpetual state of metamorphosis. Others were wise enough to know that Marco's travels included not only his journeys but also those of countless others: his father, his uncle, his predecessors, the armies of his patron, the merchants with whom he crossed paths along the Silk Road and perhaps huddled by the fire for a night.

He went on a long journey, was weary, worn-out with labour, returning he rested, he engraved on a stone the whole story.37
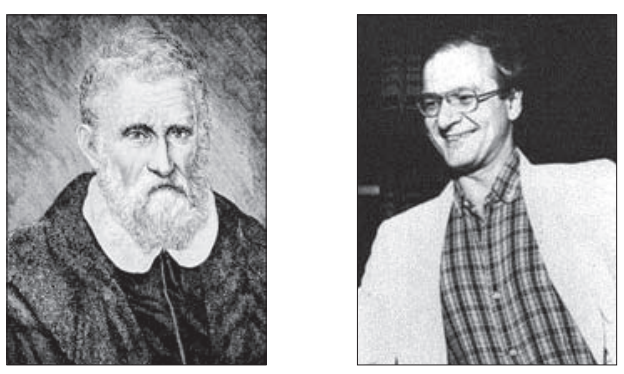

37. From the Gilgamesh legend, in Sandars, 1975, p. 61

\section{ITINERARY THREE: DAY 8}

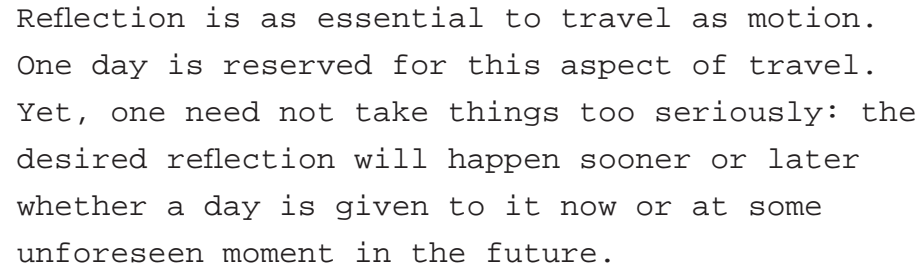




\section{Day 8: Reflections}

38. Hesse, 2006, p. 41
Siddhartha learned new things with every step along his path, for the world was transformed and his heart was enchanted... all of it had formerly been nothing for Siddhartha but a fleeting, deceptive veil before his eyes, to be regarded with distrust, penetrated by thought, and destroyed, since it was not true Being: Being lay beyond the visible..$^{8}$

Nor should we think of the attitudes exhibited in the past four days of travel as existing in isolation from one another; that is simply not possible. Perhaps they are all part of a larger overarching conception of travel, one which though the most essential is the most difficult to define. In this way, it is possible to categorize a particular aspect of Vivier's output according to more than one attitude toward travel.

The piece Bouchara, for instance, could be examined through the lens of any one of the four attitudes (as discussed over the past four days). It could be that there is something in the piece, a deeply embedded musical element, which bears a similarity to the 'classical' shash-maqam tradition of the city or to one of the numerous folk traditions of the region. However, the piece could also be considered a dream of Bukhara or an evocation of the city rather than a replication or reflection of something tangible, existent, known. The musical work forms a dialectical space wherein the composer (and performers and listeners) may engage with the mental images he possesses of the city, whatever their source. The role of the "place" is strange in an aesthetic construction such as Bouchara in that we are led to believe whatever we want to believe about the place depending simultaneously upon how we hear the piece and how we might imagine the place. It may be that Vivier only imagined travelling to Bukhara, from his arm-chair or piano bench. Without having visited the city his imagination was free to run wild over the parched plateaus and once-verdant valleys. Or perhaps he preferred to step into somebody else's shoes and retrace their steps through the city; building upon his own reactions to his proxy's impressions of the place.

Bouchara could also, and perhaps most interestingly, be viewed as a reaction toward the history of the city as an important centre on the Silk Road. Along with other quasi-legendary cities of the Silk Road such as Kashgar, Tashkent, Samarkand, Palmyra and Rhagae, the city, though stationary, has become a symbol of movement, of trade, exchange, journey, perpetual travel. Most people (at least in the West) would be hard pressed to tell you anything about the city or its people. I would venture to say that many of that group would find it difficult to find Bukhara on a map; the most objective form 
of contact with a place, a finger on a sheet of paper saying: "There it is." Yet most of those same individuals probably have heard of Bukhara. For us, Bukhara is more a city of the imagination (and an imagined past) than it is one that exists in a physical way, one in which people interact with one another in daily business. The Bukhara of our imagination is an active place but one which is highly distorted by great distances in time and space and by the lenses through which we have observed its existence, the works of literature (and other art forms) which have called to our minds a questionable, but altogether fascinating, image of the city.

In the end it may not be valid to devise four separate and distinct attitudes towards travel as the categories, upon deeper reflection, overlap, conjoin, and converse with one another. Perhaps the discussion up to this point can simply be taken as evidence in support of the argument that in addition to being a dedicated artist, Claude Vivier was also a committed itinerant. Through his art we, the arm-chair observer, may be able to see (or rather hear) the roads and paths, veins and arteries, along which Vivier wandered. Though its opposite quest overestimates the single-mindedness of the composer, it may be that "wander" is also a poor word to describe his lifelong travels in that it implies that he had no particular route in mind and travelled as the wind does.

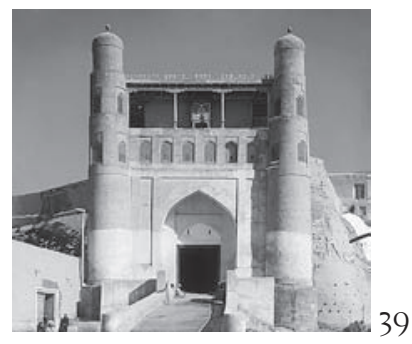

ITINERARY FOUR: DAYS 9 and 10
39. Photo of Citadel of Bukhara, Uzbekistan from $<$ http ://upload. wikimedia.org/wikipedia/commons/1/ 17/ Bokhara1909.jpg> (29 March 2008)

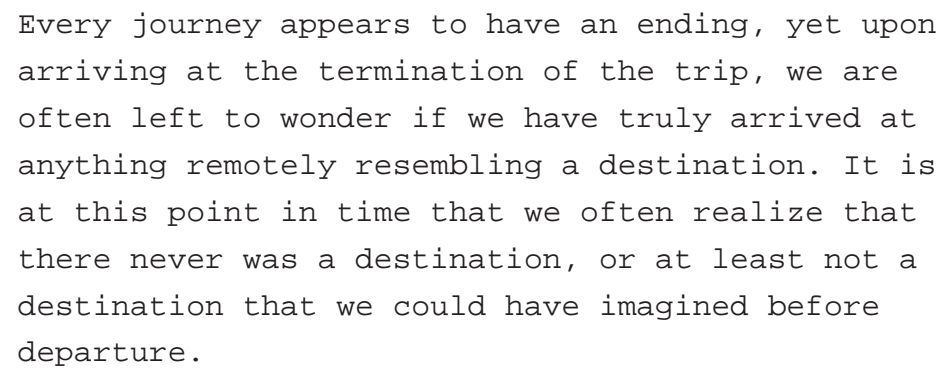




\section{Day 9: Approaching Endings}

All of this may cause one to wonder if it was the composer who was doing the travelling or if it was the various "foreign" cultures - or what he would appropriate from these cultures - which travelled to him. Like Giacinto Scelsi, perhaps Vivier can be viewed as a conduit for the artistic exploration of those places, real or imagined, which surrounded him throughout his life, a window through which the previously invisible becomes observable. This may be how Vivier would like us, whoever we are, to remember him and his music. One could also ask if Vivier somehow endeavoured, through his perpetual pursuit of travel, to erase himself from any historical context and in his place leave a reflection of himself (and this removal) as manifested in his works. Is that also what Scelsi, himself an admirer of Vivier's work, tried to do? Can we somehow relate this desire to obliterate his own "earthly" presence as part of Vivier's fascination with the greatest journey of all, death?

We draw upon the experience of human mobility to define the meaning of death (as a "passing") and the structure of life (as a "journey" or pilgrimage); to articulate changes of social and existential conditions in rites of initiation (of "passage").40

It was not necessarily death which fascinated Vivier but rather the ritual of death. The burning question was not, "what happens after death?" but "how does death happen?" To approach the ritual of death one requires a certain inner strength. If unprovoked, this inner strength often lies dormant, perhaps even completely unknown, within the individual. Countless rituals of countless cultures attempt to reconcile the individual with this inner strength. In order to have a chance at understanding death, the individual must have the courage to approach it, consider it, touch it. Without this courage, death will arrive on its own terms and strike without stopping to explain itself. Vivier's persistent travel seems to be one way in which he searched for and tested his own character in preparation for the ultimate and inevitable voyage. Certainly, his fascination with it suggests that for him death was a crucial aspect of his life and art.

This emphasis upon travel as a test, as a loss that brings a gain of stature and certainty of self, suggests that the changes of character effected by travel are not so much the introduction of something new into the personality of the traveler as a revelation of something ineradicably present-perhaps courage, perdurance, the ability to endure pain, the persistence of skills and abilities even in the context of fatigue and danger.41

What gives value to travel is fear. It is the fact that, at a certain moment, when we are so far from our own country... we are seized by a vague fear, and the instinctive desire to go back to the protection of old habits. This is the most obvious benefit of travel. At 
that moment we are feverish but also porous, so that the slightest touch makes us quiver to the depths of our being ... ${ }^{4}$

Listening to the pieces of Vivier's final years, Bouchara, Prologue pour un Marco Polo, Wo bist du Licht!, Lonely Child, one cannot help but be struck by the almost formulaic pursuit of an artistic reflection of the relationship between the journey [life?] and its unavoidable counterpart [component?] death. The fairly linear trajectory from simplicity to complexity found in these works - often expressed through the parameter of melody - is suspended at a certain point in time, usually toward the end of the piece, after which an eerie sparseness ascends to the forefront. The various journeys, or ways of envisioning a journey are superseded, for a time, by a reflection of those journeys which is both fundamentally the same and irrevocably disparate from their earlier manifestations. Linearity is replaced by a form of stagnancy which, despite its stillness, contains an even greater kinetic energy than those journeys which surround it [lead toward it?]. This may be the moment at which death descends upon the piece, yet, if the listener has been sufficiently prepared by his preceding travels, and has recognized his inner strength, the realization that the entity over there [in here?] is death becomes more powerful than death itself and he is able to survive, utterly transformed [enlightened?], but nonetheless alive.

Western thought, developing along predominantly scientific lines, tends to categorize and attempts to standardize whatever it deals with, even the arts. Often this is not in accordance with some of the basic Oriental attitudes, and sometimes it produces misunderstandings and misconceptions not only in the arts but in all forms of intercourse as well. 43
42. Albert Camus, cited in Leed, 1991, p. 1.

43. Lentz, 1965, p. 13.

44. Photo of adapted T-O Map of Hispania by St. Isidore of Seville from The History of the Cartography of Ersilia by José del Pilar Menardi Cardenio. 


\section{Day 10: Mandala}

45. Leed, 1991, p.4.

Perhaps it is only that the reality of passage had replaced the ritual, and the most important transitions we experience are written into our journeys, which make our lives a procession and spectacle more engrossing and transforming than any ritual could possibly be. 45
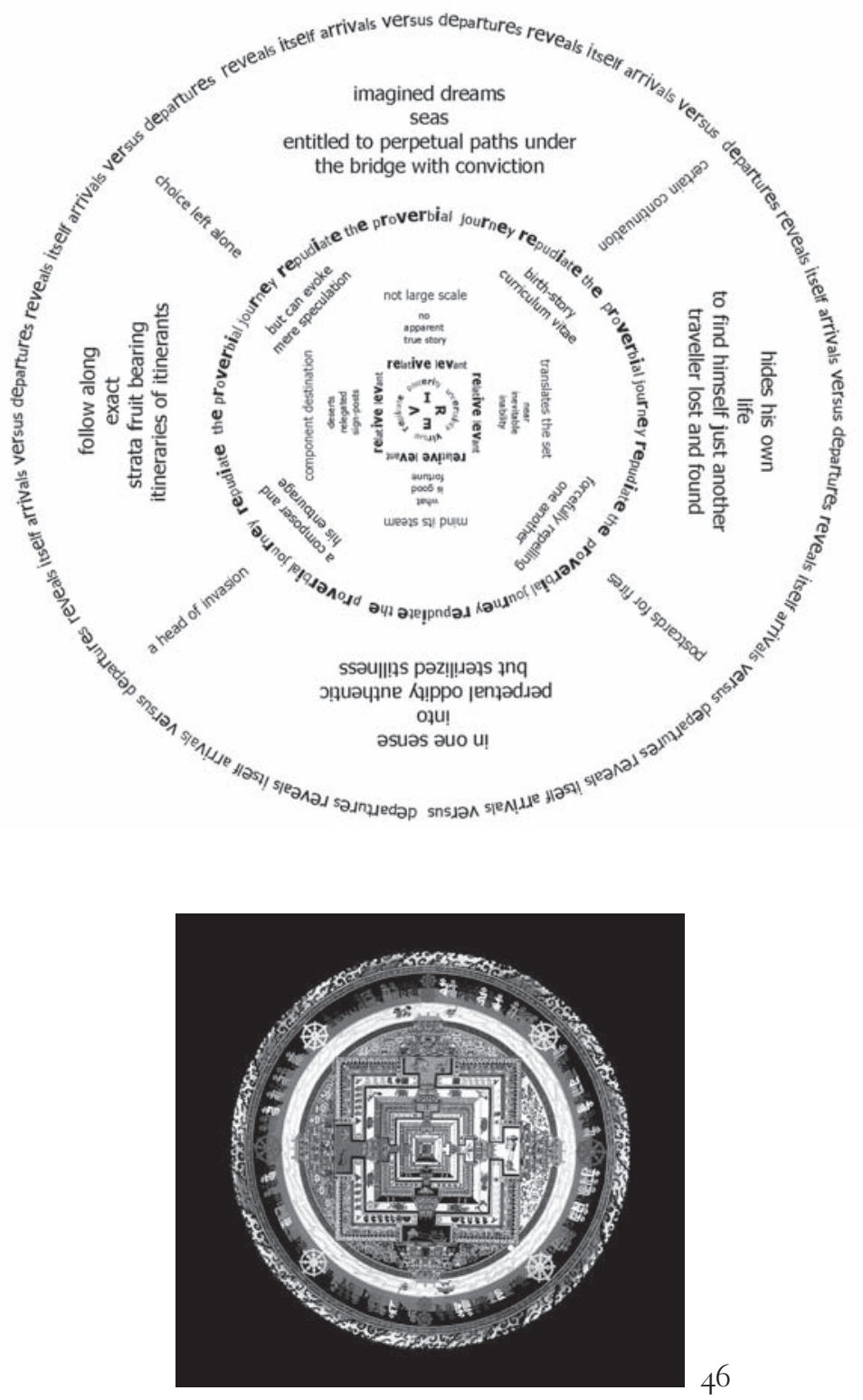

46 


\section{B I B L I O GRA P HY}

ARnold, Alison (ed.) (2000), "Hindustani Râga", in Garland Encyclopedia of World Music: Volume 5: South Asia, The Indian Subcontinent, George Ruckert and Richard Widdess (eds.), New York, Garland Publishing, p. 64-85.

Bergreen, Laurence (2007), Marco Polo: from Venice to Xanadu, New York, Alfred A. Knopf.

Blum, Alan (2003), The Imaginative Structure of the City, Montreal, McGill-Queen's University Press.

Blum, Stephen (2002), "Iran: an introduction", in The Garland Encyclopedia of World Music: Vol. 6: The Middle East, Virginia Danielson et al. (eds.), New York, Garland Publishing, Inc., p. $823-832$.

Circuit: revue Nord-Américains de Musique du xxe siècle, vol.2, nos. 1/2, 1991, Montréal, Les Presses de l'Université de Montréal.

Hesse, Hermann (2006), Siddhartha: an Indian Poem, trans. Susan Berofsky, New York, Random House, Inc.

CD: I Musici de Montréal (1988), Claude Vivier, St. Nicholas, Québec, Les éditions DobermanYppan, DO-99/4-ACM 36

LeEd, Eric J. (1991), The Mind of the Traveler: from Gilgamesh to Global Tourism. New York, Basic Books.

Lentz, Donald A. (1965), The Gamelan Music of Java and Bali: An Artistic Anomaly Complementary to Primary Tonal Theoretical Systems. Lincoln, University of Nebraska Press.

Levin, Theodore Craig and Razia Sultanova (1997-2002), 'The Classical Music of Uzbeks and Tajiks,' in The Garland Encyclopedia of World Music: Vol. 6 The Middle East. Virginia Danielson et al. (eds.), New York, Garland Pub.

Maraini, Fosco, Secret Tibet, (Revised Ed.),trans. Eric Mosbacher and Guido Waldman, London, Harvill, 2000, p. 232.

Miller, Terry E. and Sean Williams (1998), "Southeast Asian Musics: An Overview," in The Garland Encyclopedia of World Music: Volume 4: Southeast Asia, Terry E. Miller and Sean Williams (eds.), New York, Garland Publishing, Inc., p. $2-23$.

Naumkin, Vitaly (ed.) (1993), Bukhara, Reading, Garnet Publishing Ltd.

OlsEn, Dale A. (1998), "Surinam," in The Garland Encyclopedia of World Music: Volume 2: South America, Mexico, Central America and the Caribbean, Dale A. Olsen and Daniel E Sheehy (eds.), New York, Garland, p. 503-509.

SANDars, N. K. (1975), trans. The Epic of Gilgamesh, New York, Penguin Books.

Tannenbaum, Peter (1991), "Claude Vivier Revisisted", in SoundNotes,Vol.1, Toronto, p. 12 - 27.

Van den Abbele, Georges (1992) Travel as Metaphor: from Montaigne to Rousseau, Minneapolis, University of Minnesota Press.

Von Der WeID, Jean-Noël (2003), "Drowned in His Dying Song," [liner notes] in Chants... Les Jeunes Solistes Ensemble, Paris, Musique Média, p. 11-17.

Vivier, Claude (1990), Bouchara, Montreal, Canadian Music Centre.

Vivier, Claude (1989), Cinq chansons pour percussion, St. Nicholas, Quebec, DobermanYppan.

Vivier, Claude (1988), Paramirabo, St. Nicholas, Quebec, Doberman-Yppan.

Vivier, Claude (1981), Prologue pour un Marco Polo, Montreal, Canadian Music Centre.

Cinq chansons pour percussion (C) Copyright 1980 Hendon Music, Inc., a Boosey \& Hawkes company. Reproduit avec autoristation 